\title{
Regulation of Parathyroid Hormone Release and Cytosolic Calcium by Extracellular Calcium in Dispersed and Cultured Bovine and Pathological Human Parathyroid Cells
}

\author{
Meryl S. LeBoff, Dolores Shoback, Edward M. Brown, Joseph Thatcher, Ronald Leombruno, Denise Beaudoin, \\ Marguerite Henry, Richard Wilson, Johanna Pallotta, Samuel Marynick, John Stock, and George Leight \\ Endocrine-Hypertension Unit and Departments of Medicine and Surgery, Brigham and Women's Hospital, Harvard Medical School, \\ Boston, Massachusetts 02115; Division of Endocrinology, Beth Israel Hospital (J.P.), Boston, Massachusetts 02115; \\ Departments of Internal Medicine and Pathology, Baylor University Medical Center (S.M.), Dallas, Texas 75246; \\ Division of Endocrinology, Memorial Hospital (J.S.), Worcester Massachusetts 01605; and Department of Surgery, \\ Duke University Medical Center (G.L.), Durham, North Carolina 27710
}

\begin{abstract}
Alterations in parathyroid glandular sensitivity to calcium may contribute to the hypersecretion of PTH in hyperparathyroidism. Since the cytosolic calcium concentration may mediate the effects of extracellular calcium on PTH release, we have employed the calcium-sensitive intracellular dye QUIN-2 to examine the relationship between extracellular calcium, cytosolic calcium, and PTH secretion in adult, neonatal, and cultured bovine as well as pathological human parathyroid cells. PTH release was measured using $\mathbf{C}$ - and $\mathbf{N}$-terminal radioimmunoassays. Neonatal bovine parathyroid cells showed a greater set-point for secretion (the $\mathrm{Ca}^{++}$concentration causing half of the maximal inhibition of PTH release) than adult cells (1.27 \pm 0.11 vs. $1.06 \pm 0.11 \mathrm{mM}$ extracellular calcium, $P<0.01$ ), and a slightly higher extracellular calcium was necessary to raise the cytosolic calcium concentration to a given level in neonatal than in adult bovine parathyroid cells. In individual neonatal and adult cell preparations, there was a close correlation between the set-point for secretion and the "set-point" for cytosolic calcium $(r=0.832, P<0.001)$. In cells from five human parathyroid adenomas, which had an increase in setpoint for secretion, the extracellular calcium concentration necessary to raise the cytosolic calcium concentration to a given level was slightly greater than in the neonatal cells. In four preparations of human parathyroid cells there was a significant correlation between the set-points for secretion and cytosolic calcium $(r=0.856, P<0.01)$. Because neonatal bovine and pathological human parathyroid glands show cellular hyperplasia, we studied the temporal relationship between cellular proliferation and the regulation of PTH release and cytosolic calcium concentration in cultured bovine parathyroid cells. Cellular proliferation, estimated by ${ }^{3} \mathbf{H}$-thymidine incorporation,
\end{abstract}

This paper was presented in part at the 5th Annual Meeting of the American Society for Bone and Mineral Research, San Antonio, TX, 1983, abstract A51, and at the National Meeting of the American Federation for Clinical Research, Washington, DC, 1984, abstract 269A.

Address reprint requests to Dr. LeBoff, Brigham \& Women's Hospital.

Received for publication 19 April 1984 and in revised form 31 August 1984.

J. Clin. Invest.

(c) The American Society for Clinical Investigation, Inc.

0021-9738/85/01/0049/09 \$1.00

Volume 75, January 1985, 49-57 increased significantly in culture from $104 \pm 10.1$ counts/well on day 1 (first $24 \mathrm{~h}$ in culture) to $588 \pm 188$ and $6,156 \pm 649$ counts/well on days 2 and 4, respectively. In cultured cells on day 1, high $\mathrm{Ca}^{++}$(2-3 $\left.\mathrm{mM}\right)$ inhibited maximal PTH release by $58.8 \pm 3.2 \%$, which decreased significantly $(P<0.001)$ to $38.2 \pm 1.9$ and $17.1 \pm 3.7 \%$ on days 2 and 4 , respectively. The cytosolic calcium observed at $3 \mathrm{mM}$ calcium on day 1 was $701 \pm 43 \mathrm{nM}$, which declined to $466 \pm 60$ and $314 \pm 14 \mathrm{nM}$ on days 2 and $4(P<0.05)$. There was a close correlation between this progressive decrease in maximal inhibition of PTH release and the cytosolic calcium at high extracellular calcium in cultured cells $(r=0.99, P<0.001)$. Thus, during active proliferation of cultured cells, there is an alteration in the regulation of cytosolic calcium and PTH release by extracellular calcium. These results suggest that decreased sensitivity to the inhibitory effects of extracellular calcium on PTH release may result from a low cytosolic calcium at a given extracellular calcium concentration, and changes in the regulation of PTH release and cytosolic calcium by extracellular calcium may be related to enhanced cellular proliferation.

\section{Introduction}

The normal parathyroid cell shows an inverse, sigmoidal relationship between parathyroid hormone (PTH) ${ }^{1}$ secretion and the extracellular ionized calcium concentration (1-3). In a variety of settings, there may be changes in the sensitivity or "set-point" (the calcium concentration half-maximally suppressing PTH release) of the parathyroid gland for calcium. For example, parathyroid tissue from hypercalcemic, neonatal calves shows an increase in set-point for calcium both in vivo (4) and in vitro (2). In primary hyperparathyroidism, pathological parathyroid tissue shows an increase in set-point that may contribute to the hypercalcemia in this disorder (3). Parathyroid cells maintained in culture for 3-4 d also develop reduced sensitivity to the suppressive effects of calcium on parathyroid hormone release (5).

The elevated set-point for calcium in primary hyperparathyroidism may be reduced toward normal with the divalent cation ionophore A23187 (6). Moreover, increased extracellular potassium concentrations, which may decrease cytosolic calcium through an alteration in $\mathrm{Na}^{+}-\mathrm{Ca}^{++}$exchange, promote an increase in set-point in bovine parathyroid cells (7). Thus, indirect evidence suggests that changes in set-point may be

1. Abbreviation used in this paper: PTH, parathyroid hormone. 
related to alterations in the regulation of the cytosolic calcium concentration. The recent development of the calcium-sensitive intracellular dye QUIN-2 has made it feasible to determine directly the cytosolic calcium concentration in dispersed parathyroid cells (8). In the present studies, we have used QUIN2 to examine whether alterations in parathyroid cellular sensitivity to calcium might be related to changes in the relationship between the extracellular and cytosolic calcium concentrations. The results suggest that decreased sensitivity to the suppressive effects of extracellular calcium on PTH release may result from an inappropriately low cytosolic calcium concentration at a given extracellular calcium concentration, and that changes in the regulation of PTH secretion and cytosolic calcium by extracellular calcium may be related to enhanced cellular proliferation.

\section{Methods}

Dispersed bovine and human parathyroid cells were prepared by digestion with collagenase and DNase as described previously $(3,9)$. Parathyroid cells prepared in this fashion maintain high ratios of cellular potassium to cellular sodium (7) and have high levels of ATP (Brown, E. M., unpublished data). Moreover, PTH release is linear for several hours and is inhibited by up to $80 \%$ by calcium concentrations similar to those which inhibit PTH secretion in vivo (3). Dispersed parathyroid cells contained no visible fat cells by sudan staining or in cytocentrifuge preparations, and showed $>95 \%$ exclusion of trypan blue.

Dispersed bovine parathyroid cells were cultured for $4 \mathrm{~d}$ as recently described (5): cells were prepared under sterile conditions and plated onto fibronectin-coated cluster wells ( 2 or $4 \mathrm{~cm}^{2}$; Costar, Cambridge, MA) in DMEM-F12 medium with $5 \mu \mathrm{g} / \mathrm{ml}$ insulin, $15 \%$ newborn calf serum, and antibiotics (5). Plating efficiency is $\cong 34 \%$ under these conditions and the cells approach a confluent monolayer after 3-4 d. Cultured cells were removed from the plates with $0.25 \%$ trypsin (Gibco Laboratories, Grand Island, NY) in Hank's balanced salt solution with $1.0 \mathrm{mM} \mathrm{CaCl}_{2}$ and $0.5 \mathrm{mM} \mathrm{MgSO}_{4}$.

For loading with QUIN-2, parathyroid cells $\left(20 \times 10^{6} / \mathrm{ml}\right)$ were incubated with the acetoxymethyl ester of QUIN-2 (10-20 $\mu \mathrm{M})$ (Lancaster Synthesis, Ltd., Lancaster, England) at $37^{\circ} \mathrm{C}$ for $20 \mathrm{~min}$ in Eagle's minimal essential medium (Earle's salts with bicarbonate, $\mathrm{Ca}^{++}$ and $\mathrm{Mg}^{++}$deleted) supplemented with $0.02 \mathrm{M}$ Hepes (adjusted to $\mathrm{pH}$ 7.47 with $\mathrm{NaOH}$ ), $0.2 \%$ bovine serum albumin (BSA), $1.0 \mathrm{mM} \mathrm{CaCl}$, and $0.5 \mathrm{mM} \mathrm{MgSO}_{4}$ ("standard medium") (8). The cellular suspension was then diluted 10-fold with standard medium and incubated for an additional 20-60 min. The cellular pellet was washed three times with a saline solution that contained $0.025 \mathrm{M}$ Hepes (adjusted to $\mathrm{pH} 7.47$ with $\mathrm{NaOH}$ ), $125 \mathrm{mM} \mathrm{NaCl}, 5 \mathrm{mM} \mathrm{KCl}, 1 \mathrm{mM} \mathrm{CaCl}, 0.5 \mathrm{mM}$ $\mathrm{MgSO}_{4}, 1 \mathrm{gm} / \mathrm{L}$ dextrose, $1 \mathrm{mM} \mathrm{Na} \mathrm{HPO}_{4}$, and $0.1 \% \mathrm{BSA}$ ("saline"). The washed cellular pellet was resuspended in $3 \mathrm{ml}$ of the saline solution with $0.1 \%$ BSA for determination of cellular fluorescence at a cellular concentration of 7-10 $\times 10^{6}$ cells $/ \mathrm{ml}$. Fluorescence was monitored in thermostatted cuvettes $\left(37^{\circ} \mathrm{C}\right)$ in a Perkin-Elmer MPF3 spectrofluorimeter (excitation $339 \mathrm{~nm}$, emission $492 \mathrm{nM}$ ). Cellular suspensions were mechanically stirred during all experiments, except when recording was interrupted for 10-20 s during the addition of $\mathrm{CaCl}_{2}$. Extracellular calcium was raised by the addition of $0.15 \mathrm{M}$ $\mathrm{CaCl}_{2}$; direct determination of calcium concentrations in these solutions by atomic absorption spectrometry showed that they were within $3 \%$ of the calculated value. Fluorescence was monitored for 3-10 min after the addition of $\mathrm{CaCl}_{2}$, or until the signal was stable as specified below. The calibration of cellular fluorescence $(F)$ at the end of a study was achieved by cellular lysis with the detergent Triton X-100 $(0.06-0.12 \%, \mathrm{vol} / \mathrm{vol})$ in $\geq 1 \mathrm{mM}$ calcium $\left(F_{\max }\right)$, and after addition of $10 \mathrm{mM}$ EGTA and alkalinization with $1 \mathrm{M}$ Tris base (free calcium $\left.\leq 1 \mathrm{nM}, F_{\min }\right)$ to render the $\mathrm{pH}>8.3(10)$. Cytosolic calcium was then calculated from the equation: $\left[\mathrm{Ca}^{++}\right]=115 \mathrm{nM}\left(F-F_{\min }\right) /\left(F_{\max }\right.$ $-F)(10)$.

The dissociation constant for QUIN-2 used in this calculation (115 $\mathrm{nM}$ ) assumes a cytosolic free $\mathbf{M g}^{++}$which has been arbitrarily assigned a value of $1 \mathrm{mM}$ (10). Corrections were made for any changes in the autofluorescence of unloaded parathyroid cells at the same cell concentration due to the additives used in each experiment.

PTH release was assessed by incubation of QUIN-2-loaded cells (1-2 $\times 10^{6}$ cells $\left./ \mathrm{ml}\right)$ in $0.2-0.3 \mathrm{ml}$ of saline at varying extracellular calcium concentrations in parallel with studies of cellular fluorescence in $5 \mathrm{ml}$ polypropylene scintillation vials (Sarstedt, Inc., Princeton, NJ) at $37^{\circ} \mathrm{C}$ for $1-2 \mathrm{~h}$. Supernatant samples for determination of PTH were frozen after sedimentation of the cellular pellet at $250 \mathrm{~g}$ for 2 min in a desk-top centrifuge (GLC-2B, Ivan Sorvall, Inc., Norwalk, CT). We previously showed that QUIN-2-loaded neonatal bovine parathyroid cells do not differ from unloaded cells with respect to trypan blue exclusion, cellular levels of ATP and $\mathrm{K}^{+}$, and calciumregulated PTH release (8). In the present studies, maximal rates of PTH release at low calcium concentrations in QUIN-2-loaded adult bovine, cultured bovine, and pathological human parathyroid cells were $85 \%$ or more of those in unloaded cells, which suggests that loading with QUIN-2 did not adversely affect cellular viability in these cells as well.

Radioimmunoassay for PTH in samples from incubations with bovine parathyroid cells was performed in duplicate on triplicate incubation vials as previously described (9), using an anti-bovine PTH antiserum raised in a sheep, GW-1, which recognizes intact hormone and C-terminal fragments of PTH. In studies with human parathyroid cells, PTH release was determined using an $\mathbf{N}$-terminal antiserum (CK-13) raised in a chicken against hPTH(1-34) (generously donated by Dr. G. V. Segre, Massachusetts General Hospital, Boston, MA). Samples or standards [hPTH(1-34) or bPTH(1-84)] were incubated at $4^{\circ} \mathrm{C}$ for $24 \mathrm{~h}$ with the antiserum (final dilution $1: 100,000$ ) in $0.05 \mathrm{M}$ barbital, pH 8.5, with 1:6 (vol/vol) outdated human plasma. ${ }^{125} \mathrm{bPTH}(1-$ 84) was then added and the incubation continued for another 3-5 d at $4^{\circ} \mathrm{C}$. Tracer was purchased from Cambridge Nuclear Corp. (Billeria, MA) and was purified by high performance liquid chromatography (11) before use. Bound and free hormone were separated by precipitation with polyethylene glycol (9). Supernatants from incubations with dispersed human parathyroid cells generally diluted in parallel with both hPTH(1-34) and bPTH(1-84), and results were calculated in terms of either peptide. In some assays, bPTH(1-84) displaced ${ }^{125} \mathrm{IbPTH}(1-84)$ with a flatter slope than that for hPTH(1-34) or the incubation samples. In these cases, results were expressed in terms of hPTH(1-34). The reasons for the variability of the bPTH(1-84) in displacing tracer are unknown. bPTH(44-68) and bPTH(53-84) did not displace ${ }^{125} \mathrm{I}-\mathrm{bPTH}(1-84)$ at concentrations as high as $100 \mathrm{ng} /$ tube.

Cellular proliferation was determined using ${ }^{3} \mathrm{H}$-thymidine incorporation into DNA (12). After washing the cells three times in standard medium, the dispersed and cultured cells in cluster wells $\left(2 \mathrm{~cm}^{2}\right.$, Costar, Rochester, NY) were incubated with $1 \mu \mathrm{Ci} / \mathrm{ml}$ of ${ }^{3} \mathrm{H}$-thymidine (New England Nuclear, Boston, MA) in standard medium at $37^{\circ} \mathrm{C}$ for $1 \mathrm{~h}$. After sedimentation of the dispersed cells in centrifuge tubes, and aspiration of the medium from the cultured and dispersed cells, the cells were washed on ice with Dulbecco's phosphate-buffered saline (Gibco Laboratories, Grand Island, NY). The cells were then incubated in 5\% cold TCA for $15 \mathrm{~min}$. After sedimentation of the dispersed cells and aspiration of the TCA from the dispersed and cultured cells, the cells were dissolved in a total of $500 \mu \mathrm{l}$ of $1 \mathrm{~N} \mathrm{NaOH}$ and the cultured cells were then removed from the culture plates with a rubber policeman and transferred to centrifuge tubes. After the addition of $375 \mu$ l of $50 \%$ TCA and $60 \mu \mathrm{l}$ of BSA (6 mg BSA/ml sterile water) and vortexing, the precipitate was centrifuged for $5 \mathrm{~min}$ at $2,500 \mathrm{rpm}$ in a desk-top centrifuge. The resulting pellet was washed two times with 5\% TCA and resuspended in $250 \mu \mathrm{l}$ of $0.1 \mathrm{~N} \mathrm{NaOH}$. The incorporation of ${ }^{3} \mathrm{H}$ thymidine into TCA insoluble radioactivity was then determined using liquid scintillation spectrometry.

Cellular levels of calmodulin were determined by radioimmunoassay 
(Amersham Corp., Arlington Heights, IL) after extraction of cells with a buffer containing $125 \mathrm{mM}$ borate, $1 \mathrm{mM}$ EGTA, and $75 \mathrm{mM}$ sodium chloride, pH 8.4. Purified porcine calmodulin was employed as the standard in this assay because it has been previously characterized in our laboratory (13). Results obtained using this standard were similar to those obtained employing the standard provided with the radioimmunoassay kit, which is extracted from rat testes. Cellular protein was quantified using the Biorad protein method (5).

Statistical evaluation. Means have been presented with the SEM as the index of dispersion. Statistical significance was determined with the $t$ test, or regression analysis and logarithmic transformation where applicable. The null hypothesis was rejected when a $P$ value of $<0.05$ was obtained.

\section{Results}

Effect of extracellular calcium on PTH release and cytosolic calcium concentration in bovine parathyroid cells. Fig. $1 \mathrm{~A}$ shows the effects of varying extracellular calcium concentrations on PTH release from QUIN-2-loaded parathyroid cells from neonatal calves and adult cows. The data for cells from neonatal calves are similar to those shown previously (8) and are included for comparison with those for cells from cows which were studied concurrently. Maximal suppression of PTH release was comparable with adult and neonatal parathyroid tissue (70 vs. $71 \%$, respectively). Parathyroid cells from neonatal calves showed a greater maximal secretory rate at low calcium (0.5-1-mM concentrations) than those from cows $\left(5.8 \pm 0.4\right.$ vs. $2.6 \pm 0.6 \mathrm{ng} / 10^{5}$ cells $/ \mathrm{h}$, respectively, $\left.P<0.001\right)$, as well as a higher set-point for calcium $(1.27 \pm 0.11$ vs. $1.06 \pm 0.11 \mathrm{mM}$ extracellular $\mathrm{Ca}^{++}$, respectively, $P<0.01$ ).

When QUIN-2-loaded parathyroid cells from neonatal and adult parathyroid tissue were resuspended in $0.5 \mathrm{mM}$ calcium

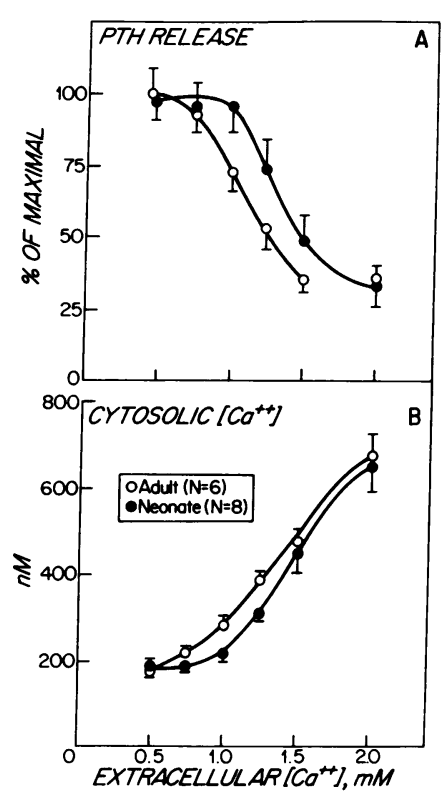

Figure 1. (A) The effects of varied extracellular calcium concentrations on PTH release in QUIN-2-loaded parathyroid cells from neonatal calves and adult cows. Incubation of parathyroid cells and measurement of PTH release were carried out as described in Methods. Each point represents the mean \pm SEM for $18-24$ observations from 6-8 experiments, each assayed in duplicate. PTH release was normalized to percentage of maximal release; absolute secretory rates are given in Results. (B) The effects of varied extracellular calcium concentrations on the cytosolic calcium concentrations in neonatal and adult bovine parathyroid cells. Parathyroid cells were loaded with the acetoxy-

methylester of QUIN-2 (10-20 $\mu \mathrm{M})$ as described in Methods. The cells were washed, and cellular fluorescence of the parathyroid cell suspension $\left(7-10 \times 10^{6}\right.$ cells $\left./ \mathrm{ml}\right)$ was determined as extracellular calcium was raised by $0.25-\mathrm{mM}$ increments by the addition of 0.15 $\mathrm{M} \mathrm{CaCl}_{2}$. Cellular fluorescence was calibrated at the end of the experiments and cytosolic calcium was calculated as described in Methods. The results represent the mean \pm SEM for 6-8 observations from 3 to 4 experiments. and exposed to progressively higher calcium concentrations, there was a stepwise increase in cellular fluorescence (not shown). When cytosolic free calcium concentrations were calculated as described in Methods, there was a corresponding rise in cytosolic calcium concentrations with increasing levels of extracellular calcium (Fig. $1 B$ ). Cytosolic calcium increased more at lower levels of extracellular calcium in cells from adult than in those from neonatal parathyroid tissue, although this difference was not statistically significant by $t$ testing.

The relationship between the effect of extracellular calcium on cytosolic calcium and PTH release in neonatal and adult parathyroid tissue. The results shown in Fig. 1 suggested that changes in the sensitivity of the secretory process to extracellular calcium might be related to alterations in the relationship between the extracellular and cytosolic calcium concentrations. To investigate this possibility further, the set-point for secretion was plotted against the cytosolic calcium concentration at the set-point in a series of cell preparations from neonatal and adult bovine parathyroid tissue (Fig. $2 A$ ). The cytosolic calcium concentration associated with half-maximal inhibition of secretion was independent of the set-point for PTH release, which suggests that inhibition of hormonal secretion occurred at similar cytosolic calcium concentrations regardless of the extracellular calcium concentration necessary to modify these parameters. For each cell preparation, the set-point for secretion was then plotted against the "set-point" for cytosolic calcium or the extracellular calcium concentration necessary to achieve the average cytosolic calcium concentration associated with the secretory set-point for all the cell preparations (i.e., 308 nM, see Fig. $2 A$ ) (Fig. $2 B$ ). There was a close correlation ( $r=0.832, P<0.001$ ) between these parameters for cell preparations from neonatal and adult bovine parathyroid tissue with set-points ranging from 0.93 to $1.48 \mathrm{mM}$.

Effect of varying extracellular calcium concentrations on cytosolic calcium concentration and PTH release in pathological human parathyroid tissue. Fig. 3 shows the relationship between the extracellular and cytosolic calcium concentrations in dispersed parathyroid cells from 12 adenomas and five glands from four patients with uremic secondary hyperparathyroidism. In cells from these pathological human parathyroid glands, the extracellular calcium concentration necessary to raise the cytosolic calcium concentration to a given level was comparable to or greater than that for neonatal bovine parathyroid cells.

For studies on the effects of extracellular calcium on PTH release in human parathyroid tissue, an $\mathrm{N}$-terminal antiserum was employed to minimize the interpretational difficulties inherent with the use of antisera recognizing inactive, C-terminal fragments of the hormone. The characteristics of this assay are described in Methods. Preliminary studies with bovine parathyroid cells showed that the set-point for secretion was identical when measured with the $\mathrm{N}$ - and C-terminal assays (1.2 \pm 0.045 and $1.2 \pm 0.054 \mathrm{mM}$, respectively, $n=3)$, although maximal suppressibility was slightly greater with the $\mathrm{N}$-assay $(70 \pm 4.5$ vs. $54 \pm 1.5 \%)$.

PTH release as a function of the extracellular calcium concentration was measured in dispersed parathyroid cells from five adenomas and three glands from patients with uremic secondary hyperparathyroidism. Set-points using the $\mathrm{N}$-terminal assay for the adenomas and tissue showing secondary hyperplasia were comparable to those we have found previously using a C-terminal assay $(1.33 \pm 0.15$ vs. $1.26 \pm 0.13$ 

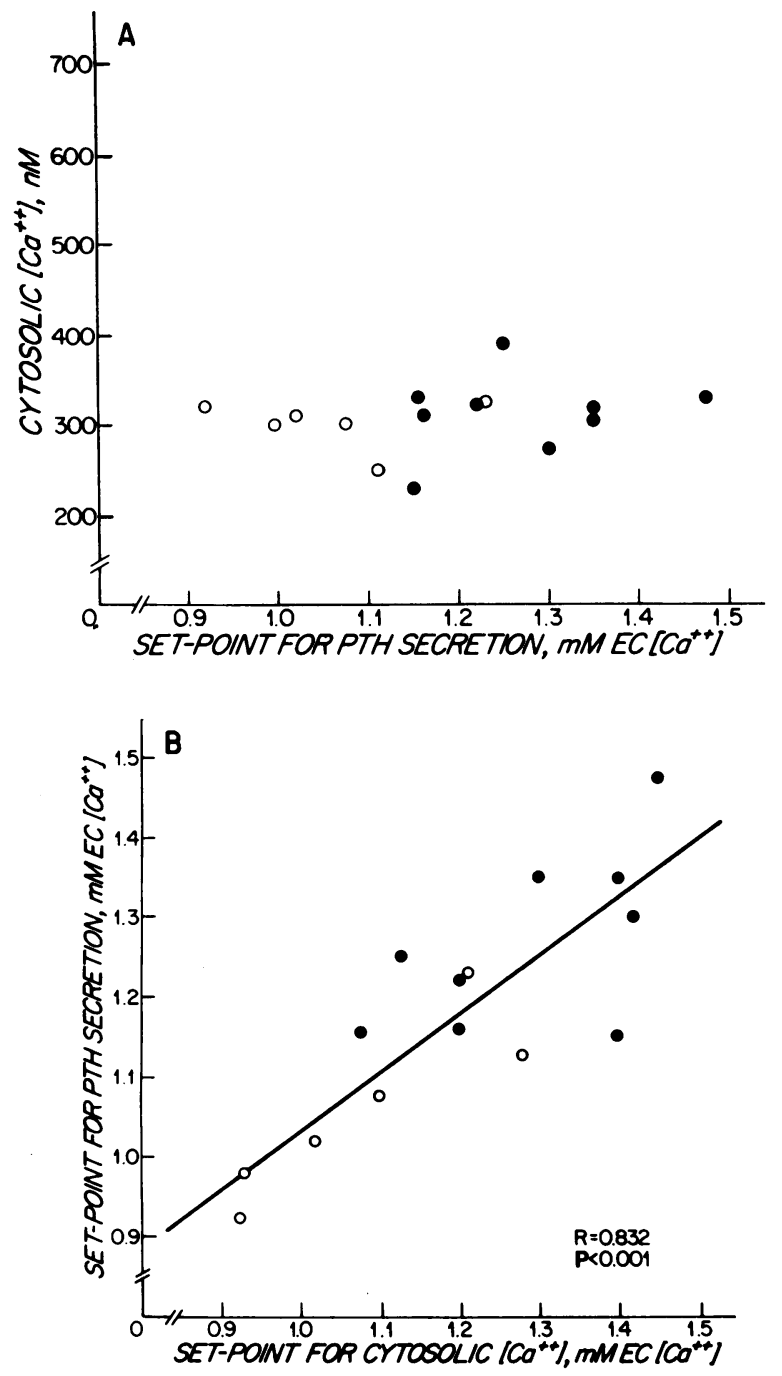

Figure 2. (A) The relationship between the set-point for secretion (calcium concentration causing half-maximal inhibition of PTH release) and the cytosolic calcium concentration at the secretory setpoint in cell preparations from neonatal $(\bullet)$ and adult $(0)$ bovine parathyroid tissue. The average cytosolic calcium associated with the secretory set-point was $308 \mathrm{mM}$. $(B)$ The relationship between the set-point for secretion and the extracellular calcium concentration necessary to achieve the average cytosolic calcium concentration associated with the secretory set-point $(308 \mathrm{mM})$ ("set-point for cytosolic calcium") in neonatal and adult bovine parathyroid cells. The secretory set-points ranged from 0.93 to $1.48 \mathrm{mM}$. There was a close correlation between these parameters $(r=0.832, P<0.001)$.

and $1.22 \pm 0.03$ vs. $1.17 \pm 0.19$, respectively) (14). Figs. 4 and 5 show a comparison between the effects of extracellular calcium on cytosolic calcium and PTH secretion in cell preparations from four adenomas. In three, changes in PTH release and cytosolic calcium occurred at similar levels of extracellular calcium (Fig. 4). In one cell preparation, however, despite extracellular calcium-induced increases in cytosolic calcium comparable to those with adult bovine parathyroid tissue, there was markedly impaired suppression of PTH release (Fig. 5).

In four cell preparations in which there was $>50 \%$ suppression of PTH secretion by 2-3 mM calcium, the cytosolic calcium concentration at which PTH release was half-maximally

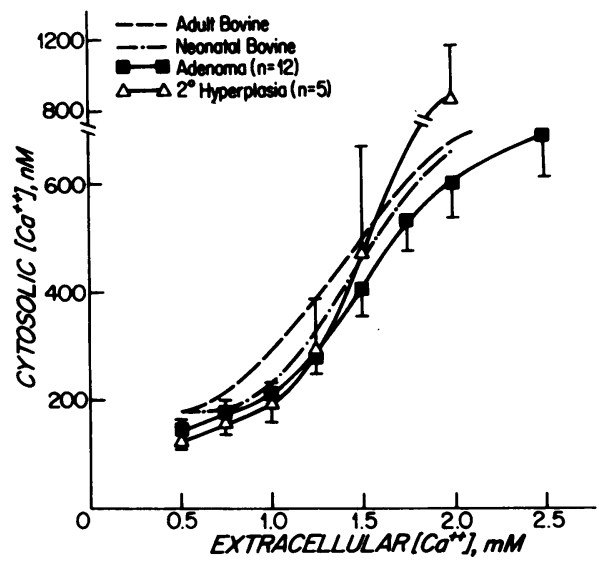

Figure 3. The relationship between the extracellular and cytosolic calcium concentrations in human parathyroid cells from 12 adenomas and five glands from four patients with uremic secondary hyperparathyroidism. Cellular loading with QUIN 2 and measurement and calibration of fluorescence were carried out as described above.

suppressed averaged $304 \mathrm{nM}$, nearly identical to that for bovine parathyroid cells ( $308 \mathrm{nM}$; see above). In addition, as with adult and neonatal bovine tissue, there was a significant correlation between the set-point for secretion and the extracellular calcium concentration necessary to raise the cytosolic calcium concentration to the average value at which PTH release was half-maximally suppressed $(r=0.856, P<0.01)$ (Fig. 6).

Effect of extracellular calcium on PTH secretion and cytosolic calcium concentration in cultured bovine parathyroid cells as a function of the culture interval. We recently found that bovine parathyroid cells proliferating in culture over 3-4 d lose normal suppressibility of PTH release by extracellular calcium similar to the most severe abnormalities in parathyroid adenomas (5). Because this parathyroid cell culture system might provide a model for investigating the changes in parathyroid function in hyperparathyroidism, we examined the relationship between the regulation of PTH release and cytosolic

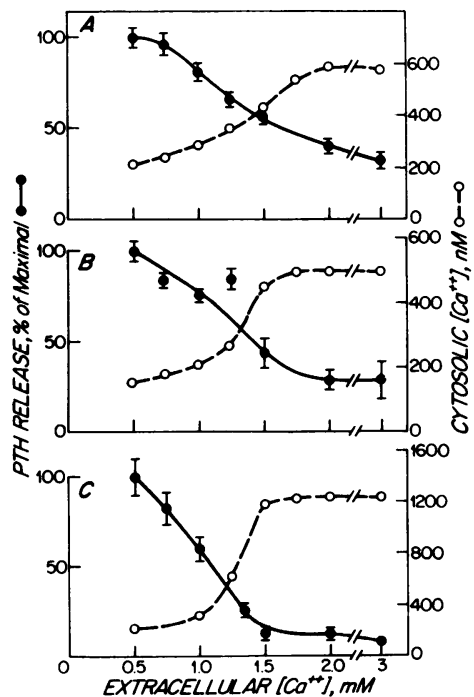

Figure 4. The relationship between the effect of extracellular calcium on cytosolic calcium and PTH release in cells from three parathyroid adenomas. PTH release (mean \pm SEM) was determined as described in Methods after incubation at $37^{\circ} \mathrm{C}$ for $1-2 \mathrm{~h}$ Radioimmunoassay for PTH was performed in duplicate on triplicate incubation vials using an $\mathrm{N}$-terminal assay as described in Methods. Cytosolic calcium was measured after the cells were loaded with 10-20 $\mu \mathrm{M}$ QUIN-2 as described in Fig. 1. Maximal rates of PTH release were 5.2, 2.7, and $0.93 \mathrm{ng} / \mathrm{bPTH}(1-84)$ equivalent $/ 10^{5}$ cells per $\mathrm{h}$ in $A, B$, and $C$, respectively. 


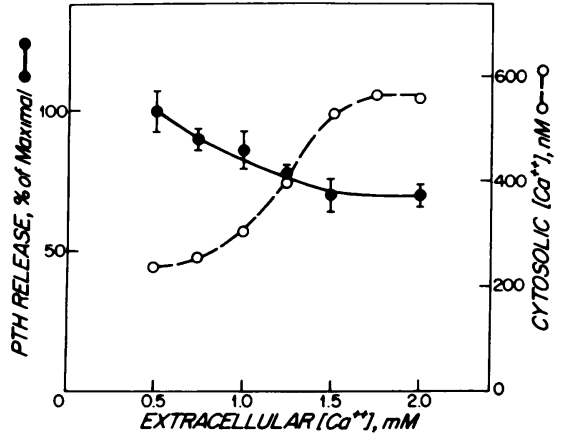

Figure 5. The relationship between the effect of extracellular calcium on cytosolic calcium and PTH release in one parathyroid adenoma. PTH release and cytosolic calcium were determined as described above. PTH release was inhibited by $29 \%$ of maximal and the cytosolic calcium concentration increased to $565 \mathrm{nM}$ at $2 \mathrm{mM}$ extracellular calcium. The maximal rate of PTH release was $183 \mathrm{pg} \mathrm{hPTH}$ (1-34) equivalent $/ 10^{5}$ cells per $h$.

calcium by extracellular calcium in cultured cells. Fig. $7 \mathrm{~A}$ demonstrates the effect of extracellular calcium on PTH secretion in QUIN-2-loaded, cultured neonatal bovine parathyroid cells as a function of the culture interval, and in acutely dispersed, neonatal bovine parathyroid cells for comparison (8). The sequential changes start with day 1 , or the first $24 \mathrm{~h}$ in culture. Similar to acutely dispersed cells, which display a $50-75 \%$ inhibition of maximal PTH release at high extracellular calcium (2-3 mM), cultured parathyroid cells on day 1 showed a $58.8 \pm 3.22 \%$ inhibition of maximal PTH release $(n=12)$ (Fig. $7 \mathrm{~A}$ ). The set-point in cultured cells on day 1 was 1.35 $\mathrm{mM}$ calcium, slightly higher than the value of $1.30 \mathrm{mM}$ calcium observed with acutely dispersed cells. As cultured parathyroid cells proliferated in culture, however, the percentage of maximal inhibition of PTH release decreased to *38.2 $\pm 1.86 \%$ $(n=14)$ on day 2 and then to $* 17.1 \pm 3.73 \%$ on day 4 as the cells approached confluency $\left({ }^{*} P<0.001\right.$ compared with day

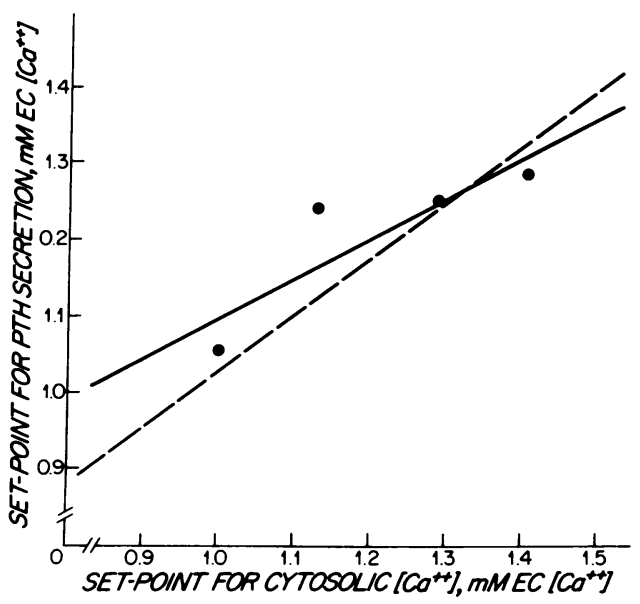

Figure 6. The relationship between the set-point for secretion and the set-point for cytosolic calcium (the extracellular calcium concentration necessary to raise the cytosolic calcium concentration to the average value at which PTH release was half-maximally suppressed) in four parathyroid adenomas. There was a close correlation $(r=0.856, P<0.01)$ between these two parameters (solid line). The dashed line indicates the relationship between these parameters for bovine parathyroid cells.

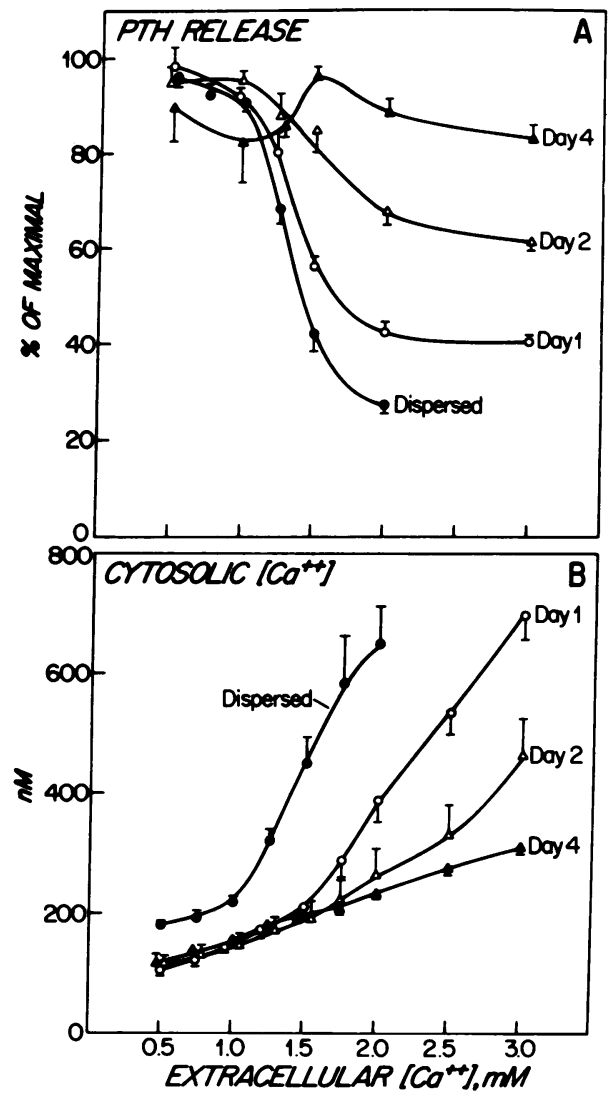

Figure 7. (A) The effect of extracellular calcium on maximal PTH release in dispersed and cultured neonatal bovine parathyroid cells as a function of the culture interval. PTH release (percentage of maximal) was determined in QUIN-2-loaded parathyroid cells as described in Methods. Absolute secretory rates are given in Results. Each point represents the mean \pm SEM from 6 to 30 observations each assayed in duplicate on triplicate incubation vials. $(B)$ The effect of extracellular calcium on cytosolic calcium concentration in dispersed and cultured bovine parathyroid cells as a function of the culture interval. Cytosolic calcium was measured as described in Methods. Each point represents the mean \pm SEM from 4 to 13 experiments.

1). While acutely dispersed, neonatal cells showed a maximal secretory rate of $5.8 \pm 0.4 \mathrm{ng} \mathrm{PTH} / 10^{5}$ cells/h $(n=30)$, the maximal secretory rate in cultured cells removed from culture plates with trypsin (see Methods) was 3.38 $\pm 0.215,2.60 \pm 0.279$, and 4.16 $\pm 0.474 \mathrm{ng}$ PTH $/ 10^{5}$ cells per $h$ on days 1,2 , and 4, respectively ( $n=6-15)$. Because maximal hormonal secretion was less than previously reported in cultured cells incubated on the culture plates compared with those exposed to trypsin $\left(9.3 \pm 0.8\right.$ vs. $4.16 \pm 0.474 \mathrm{ng} \mathrm{PTH} / 10^{5}$ cells/h on day 4$)(5)$, we studied the effects of high calcium (2-3 mM) on the inhibition of maximal PTH release in cells on the culture plates and those exposed to trypsin. In cultured cells in culture wells vs. those trypsinized and incubated in scintillation vials, the percentage of maximal suppression of PTH secretion at high calcium was $* 55.5 \pm 2.06$ vs. $58.8 \pm 3.22 \%$ on day $1,{ }^{*} 38.6 \pm 4.45$ vs. $38.2 \pm 1.86 \%$ on day 2 , and, as shown previously, ${ }^{*} 19.44 \pm 4.18$ vs. $17.1 \pm 3.73 \%$ on day $4\left({ }^{*} P<0.05, n=12\right.$ 24) (5). Thus, while trypsinization may have contributed to the reduced maximal secretory rate observed here, it had no effect on the sensitivity of the parathyroid cells to calcium. 
To assess whether the progressive reduction in the sensitivity of PTH release to extracellular calcium in cultured cells was due to a change in the relationship between the extracellular and cytosolic calcium concentrations, we measured the cytosolic calcium concentration in cultured cells. The effects of varied extracellular calcium concentrations on the cytosolic free calcium concentrations in cultured cells studied sequentially from days 1-4 are shown in Fig. $7 \mathrm{~B}$. The cytosolic calcium concentrations of dispersed parathyroid cells at varied extracellular calcium concentrations are also included in Fig. $7 B$ for comparison. On day 1, before the development of the reduced sensitivity of PTH secretion to extracellular calcium in cultured parathyroid cells, basal cytosolic calcium concentration decreased from $179 \pm 7.6 \mathrm{nM}$ in dispersed to $106 \pm 8.5$ nM in cultured cells $(P<0.001)$, and there was a shift in the relationship between extracellular and cytosolic calcium concentrations to the right, which indicated that a higher extracellular calcium concentration was necessary to raise the cytosolic calcium concentration to a level comparable to that in the dispersed cells (Fig. 7 B). At $3 \mathrm{mM}$ extracellular calcium, however, the cultured cells on day 1 achieved a cytosolic calcium concentration of $701 \pm 43.1 \mathrm{nM}(n=4)$, which was not significantly different from the value of $646 \pm 68 \mathrm{nM}$ observed in dispersed cells at $2 \mathrm{mM}$ extracellular calcium $(P$ $>0.05$ ). With the decline in calcium sensitivity of PTH release to extracellular calcium in cultured cells on day 2 and subsequently on day 4 , the cytosolic calcium concentration achieved at high extracellular calcium $(3 \mathrm{mM})$ was $* 466 \pm 59.7 \mathrm{nM}$ on day 2 and ${ }^{* *} 314 \pm 13.5 \mathrm{nM}$ on day 4 of the culture interval $\left({ }^{*} P<0.05\right.$ and ${ }^{* *} P<0.001$, compared with day 1$)$. Using linear regression analysis, the progressive decrease in the percentage of maximal inhibition of PTH release in cultured cells correlated with the reduced rise in cytosolic calcium concentration at $3 \mathrm{mM}$ extracellular calcium from day 1 to day $4(r=0.99, P<0.001)$.

To exclude the possibility that the reduced rise in cytosolic free calcium concentration was a consequence of a change in the amount of the calcium-binding protein calmodulin, we measured the amount of calmodulin corrected for cellular protein in cellular extracts of cultured cells from day 1 to day 4. The amount of calmodulin in cultured cells on days 1,2 , and 4 was $4.6 \pm 1.2,4.1 \pm 0.3$, and $3.6 \pm 0.3 \mu \mathrm{g} / \mathrm{mg}$ of protein, respectively $(n=6-7, P>0.05)$.

Cellular proliferation in dispersed and in cultured bovine parathyroid cells as a function of the culture interval. To examine the association between changes in cellular proliferation and the regulation of PTH release and cytosolic calcium by extracellular calcium, we studied ${ }^{3} \mathrm{H}$-thymidine incorporation into DNA in acutely dispersed and cultured bovine parathyroid cells as a function of the culture period. The ${ }^{3} \mathrm{H}$-thymidine incorporation into DNA in acutely dispersed cells was $35.7 \pm 5.24$ counts $^{2}(n=23)$. As demonstrated in Fig. 8, DNA synthesis increased significantly in cultured bovine parathyroid cells, resulting in an increase in ${ }^{3} \mathrm{H}$-thymidine incorporation from $* 104 \pm 10.1$ counts/well on day 1 to $* * 588 \pm 188$ counts/ well on day 2 and ${ }^{*} 6,156 \pm 649$ counts/well on day $4\left({ }^{*} P\right.$ $<0.001$, and ${ }^{* *} P<0.01$, compared with acutely dispersed

2. ${ }^{3} \mathrm{H}$-Thymidine incorporation in acutely dispersed cells was measured in 170,000 cells which corresponded to the number of viable cells per well after $15-17 \mathrm{~h}$ in culture.

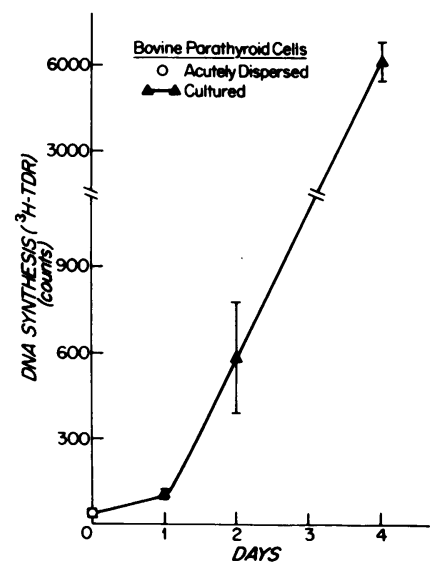

Figure $8 .{ }^{3} \mathrm{H}$-thymidine incorporation into DNA in acutely dispersed cells ${ }^{2}$ and cultured bovine parathyroid cells (counts [cpm]/well) as a function of days in culture. The cells were incubated with $1 \mu \mathrm{Ci} / \mathrm{ml}$ of ${ }^{3} \mathrm{H}$-thymidine in standard medium at $37^{\circ} \mathrm{C}$ for $1 \mathrm{~h}$. The incorporation of ${ }^{3} \mathrm{H}$ thymidine into TCA-insoluble radioactivity was then determined as described in Methods. Each point represents the mean \pm SEM of 17-24 observations.

cells, $n=17-21$ ). We have previously shown that viable cell number increased significantly from $289,000 \pm 63,000$ cells/ well on day 1 to $530,000 \pm 60,000$ cells/well on day $4(n=6$; $P<0.02)$. This increment in cell number, when plotted semilogarithmically against time, revealed a doubling time of $\sim 4 \mathrm{~d}$. Total cellular protein also increased significantly from $40.00 \pm 1.40 \mu \mathrm{g} /$ well on day 1 to $177.60 \pm 57.10 \mu \mathrm{g} / \mathrm{well}$ on day $4(n=9 ; P<0.035)$ (5). Thus, this 59-fold increase in ${ }^{3} \mathrm{H}$-thymidine incorporation from day 1 until day 4 corresponded to an approximately twofold increment in cell number and fourfold increase in cellular protein (5). Autoradiographic studies on near confluent monolayers of cultured parathyroid cells (day 4) revealed uptake of $\left[{ }^{3} \mathrm{H}\right]$ thymidine predominantly in the parathyroid cells, with only $6.73 \pm 1.26 \%$ of the labeled nuclei representing spindle-shaped cells, which were presumably fibroblasts $(n=4)$. There was a significant correlation between the temporal changes in ${ }^{3} \mathrm{H}$-thymidine incorporation and both maximal suppression of PTH release $(r=-0.997, P<0.01)$ as well as cytosolic calcium concentration $(r=-0.995$, $P<0.01)$ at high extracellular calcium $(2-3 \mathrm{mM})$.

\section{Discussion}

The mechanisms by which extracellular calcium regulates PTH release have not been established with certainty. We recently showed a close correlation between the effects of extracellular calcium on PTH release and cytosolic calcium in dispersed bovine parathyroid cells (8). Since the effects of elevated extracellular calcium concentrations on PTH release can be mimicked by addition of the divalent cation ionophore ionomycin at a fixed calcium concentration (15), the cytosolic calcium concentration per se may be an important intracellular mediator of hormonal secretion. It is possible, therefore, that alterations in the sensitivity of parathyroid tissue to extracellular calcium result from changes in the relationship between the extracellular and cytosolic calcium concentrations. The present results suggest that there is a close relationship between the effects of extracellular calcium on cytosolic calcium and PTH release in bovine and pathological human parathyroid tissue with widely varying sensitivities to calcium.

Keaton et al. (4) have demonstrated in vivo that neonatal calves, unlike adult cows, are hypercalcemic, and display reduced sensitivity to the inhibitory effects of calcium on PTH release. Our in vitro studies have confirmed and extended these observations by showing that the set-point for secretion 
was significantly greater in neonatal than adult bovine parathyroid cells ( 1.27 vs. $1.06 \mathrm{mM}$ calcium), and that in neonatal parathyroid cells a higher extracellular calcium concentration was necessary to raise the cytosolic calcium concentration to a level comparable to that in the adult bovine cells (Fig. $1 \mathrm{~B}$ ). Moreover, our results indicated that changes in PTH release were closely linked to changes in the cytosolic calcium concentration, in that there was a significant correlation between the set-point for secretion in neonatal and adult bovine parathyroid cells and the extracellular calcium concentration necessary to achieve the mean cytosolic calcium concentration (308 $\mathrm{nM})$, at which half-maximal inhibition of PTH release occurred (Fig. $2 B)(r=0.832, P<0.001)$.

Keaton et al. (4) have suggested that the increase in parathyroid glandular set-point for calcium and associated hypercalcemia in the neonatal calf may be a model for human hyperparathyroidism. In fact, there is a decreased sensitivity to the suppressive effects of extracellular calcium on PTH release in both primary and secondary hyperparathyroidism (16-18). It was of interest, therefore, to compare the effects of extracellular calcium on cytosolic calcium and PTH release in pathological human parathyroid cells.

Because bPTH(1-84) and supernatants from human parathyroid cells do not dilute in parallel in our C-terminal PTH assay, we used an N-terminal assay to compare the effects of extracellular calcium on PTH release and cytosolic calcium in pathological human parathyroid tissue. In addition, the use of an $\mathrm{N}$-terminal assay largely obviates the difficulties inherent in interpreting secretory data in which there may be release of inactive C-terminal fragments of PTH. While characterizing this assay, we observed that the set-points for secretion in primary and secondary hyperparathyroidism using the $\mathrm{N}$-terminal assay were similar to those we reported previously using a C-terminal assay $(1.33 \pm 0.15$ vs. $1.26 \pm 0.13$ and $1.22 \pm 0.03$ vs. $1.17 \pm 0.19 \mathrm{mM}$, respectively) (14). In addition, the set-points for secretion in neonatal bovine parathyroid cells were identical in the $\mathrm{N}$ - and C-terminal assays (1.2 \pm 0.045 and 1.2 \pm 0.054 , respectively). These results suggest that the two assays yield comparable estimates of parathyroid cellular sensitivity to calcium.

In parathyroid adenomas, a slightly greater extracellular calcium was necessary to raise the cytosolic calcium to a given level than in neonatal bovine cells, which is consistent with the slightly higher secretory set-point in the former. In four of five adenomas studied here, changes in PTH release and cytosolic calcium occurred over a similar range of extracellular calcium concentrations. Moreover, the cytosolic calcium concentration at which there was half-maximal inhibition of PTH secretion was nearly identical to the value found in dispersed bovine parathyroid cells ( 304 vs. $308 \mathrm{nM}$, respectively). As with the adult and neonatal bovine parathyroid cells, there was a significant correlation in a small number of cases between the set-point for secretion and the set-point for cytosolic calcium, or the extracellular calcium concentration necessary to raise cytosolic calcium concentration to the average value at which PTH was half-maximally suppressed $(r$ $=0.856, P<0.01)$. This suggests that the sensitivity of PTH secretion to calcium in bovine as well as pathological human parathyroid tissue is related to the cytosolic calcium concentration.

In one parathyroid adenoma, however, there was only $29 \%$ suppression of maximal PTH release at $2 \mathrm{mM}$ calcium despite an increase in the cytosolic calcium to levels comparable with that in adult bovine parathyroid cells. The poor suppressibility of this cell preparation in the presence of an elevated cytosolic calcium suggests a defect distal to the mechanisms which regulate the cytosolic calcium concentration. We have previously shown that there is considerable heterogeneity in the suppressibility of PTH release from pathological human parathyroid tissue by calcium $(3,16)$. Unlike hyperparathyroid tissue, which displayed a $\geq 50 \%$ suppression of PTH release and a reduction in the set-point for calcium in the presence of the calcium ionophore A23187, parathyroid adenomas that were resistant to the effects of extracellular calcium on hormone secretion also showed no effects of the calcium ionophore on PTH secretion (6). Thus, it is possible that there are two defects in hyperparathyroidism, one in which the resistance to the suppressive effects of extracellular calcium on PTH release results from an inappropriately low cytosolic calcium at a given extracellular calcium concentration, and the other in which there is a defect at a site distal to regulation of the cytosolic calcium concentration. Alternatively, factors in addition to the cytosolic calcium concentration may control the effects of calcium on PTH release.

In the absence of data relating changes in extracellular calcium concentration to alterations in cytosolic calcium concentration in normal human parathyroid cells, results with pathological human parathyroid cells must be interpreted with caution. The set-point for normal human glands, however, is close to that for adult cows (1.0 vs. $1.06 \mathrm{mM}$, respectively) (3). Moreover, the similarity in the relationship between changes in the sensitivity of PTH release and cytosolic calcium in bovine and pathological human parathyroid cells suggests a close linkage between the regulation of cytosolic calcium and hormonal secretion in both species.

Pathological human $(3,16-18)$ and neonatal bovine $(2,4)$ parathyroid tissue both show alterations in the regulation of PTH release by extracellular calcium and increases in parathyroid cell mass (19-21), which suggest an association between changes in parathyroid cell secretory function and enhanced cellular proliferation. Our recent development of in vitro techniques for establishing primary cell cultures of bovine parathyroid cells (5) has enabled us to investigate the relationship between cellular replication and parathyroid secretory function. As cultured parathyroid cells proliferated in vitro, there was a gradual decline in the sensitivity of PTH release to extracellular calcium, which correlated with a progressive decrease in the cytosolic calcium concentration at high calcium ( $r=0.99, P<0.001$ ). Thus, like neonatal bovine parathyroid cells and parathyroid adenomas, the reduced sensitivity of PTH secretion to extracellular calcium in cultured bovine parathyroid cells appears to be related to this decreased rise in cytosolic calcium relative to extracellular calcium.

Because an increase in the amount of the calcium-binding protein calmodulin might lead to an enhanced buffering capacity for calcium, thereby producing a decrease in the cytosolic free calcium concentration, we measured the amount of calmodulin in cultured cells. These results revealed that the amount of calmodulin corrected for cellular protein did not change over the culture interval and could not, therefore, account for the decrease in the cytosolic free calcium concentrations at high extracellular calcium concentrations.

To define further the association between the changes in secretory function and cellular proliferation, we studied the 
temporal relationships between changes in cellular proliferation and the regulation of PTH release and cytosolic calcium by extracellular calcium over the culture interval. Cultured cells undergo a 59-fold increment in ${ }^{3} \mathrm{H}$-thymidine incorporation into DNA between days 1 and 4. As shown previously, this increase in ${ }^{3} \mathrm{H}$-thymidine incorporation over $4 \mathrm{~d}$ corresponded to a twofold increment in cell number and a fourfold increase in cellular protein (5). DNA synthesis was initiated within the first $24 \mathrm{~h}$ of the culture period, as ${ }^{3} \mathrm{H}$-thymidine incorporation DNA on day 1 was significantly greater than the $35.7 \pm 5.24$ counts observed in acutely dispersed cells. Preceding the development of the reduced sensitivity of hormonal secretion to extracellular calcium, there was a significant decrement in the basal cytosolic calcium concentration on day 1 which coincided with the onset of active cellular proliferation. It is possible, then, that this low cytosolic calcium concentration promoted the enhanced cellular proliferation observed in these cells and that, as postulated by Parfitt (22) and others, the parathyroid cell divides to maintain an increased hormonal output at a lower calcium concentration. The changes in cellular proliferation as a function of the culture interval correlated significantly with the gradual reduction in the effects of high extracellular calcium on PTH release $(r=0.997, P<0.01)$ and cytosolic calcium $(r=0.995, P<0.01)$. Although it is possible that the increment in ${ }^{3} \mathrm{H}$-thymidine incorporation into DNA observed in the cultured cells was due to the enhanced cellular proliferation of other cell types, such as fibroblasts, autoradiographic studies revealed uptake of ${ }^{3} \mathrm{H}$-thymidine predominantly in parathyroid cells. Moreover, while the change in ${ }^{3} \mathrm{H}$-thymidine incorporation into DNA could have been a consequence of an increase in the intracellular pool of thymidine, or a decrease in thymidylate synthetase (12), three parameters of cellular proliferation provided evidence that cellular proliferation was enhanced in vitro. Thus, in cultured bovine parathyroid cells, with the onset and during the active period of cellular proliferation, there is an alteration in the regulation of cytosolic calcium and PTH release by extracellular calcium, which indicates that there is an association between changes in cellular proliferation and secretory function.

Because of the similarities between cultured bovine parathyroid cells and neonatal bovine and pathological human parathyroid cells, it is possible that the abnormal secretory function in the latter two cell types may be causally related to enhanced proliferative activity as well. Although we did not determine ${ }^{3} \mathrm{H}$-thymidine incorporation or other indices of cellular proliferation in pathological cells, it is of interest that Lloyd et al. (23) measured ${ }^{3} \mathrm{H}$-thymidine incorporation in parathyroid adenomas and found that DNA synthesis correlated with the preoperative serum PTH and calcium concentration, but not with tumor weight. These studies suggest that more severe secretory abnormalities are produced by parathyroid adenomas undergoing more active cellular proliferation.

Differentiated cellular function may be controlled by the state of cellular proliferation. As demonstrated in other tissues, rapidly proliferating cells may lose the ability to express certain physiologic characteristics $(24,25)$. Inhibition of cellular replication, for example, by causing a growth arrest in the $\mathbf{G}_{1}$ stage of the cell cycle, has, in turn, induced the differentiated function of certain cells. Growth arrest in the $G_{1}$ stage of the cell cycle has been achieved by contact inhibition of proliferating cells, or by growing the cells in a medium deficient in growth factors or other nutrients (26-28). A reduction in the prolif- erative activity of cultured parathyroid cells, or possibly parathyroid adenomas, may therefore result in the normalization of the phenotypic expression of these cells. A further understanding of the association between changes in proliferation and cellular function may provide important clues to the pathogenesis and perhaps treatment of hyperparathyroidism and other endocrine neoplasias.

\section{Acknowledgments}

The authors gratefully acknowledge the expert secretarial assistance of Ms. Diane Rioux, Mrs. Nancy Orgill, and Mrs. Carmen Quintero. Furthermore, the authors are grateful for the cooperation of Dr. Miller S. Bell, Dr. Z. H. Lieberman, Dr. N. Y. Zachariah, and Mrs. Julie Osborne in providing parathyroid tissue from the Baylor University Medical Center, Dallas, TX.

This work was supported by U. S. Public Health Service (USPHS) grants AM25910 and AM30028, as well as by American Cancer Society grant PDT 230. Dr. Brown is the recipient of USPHS grant RCDA 5K0 4AM00627. Dr. LeBoff is a recipient of USPHS grant CIA IK08AM 01198-01.

\section{References}

1. Sherwood, L. M., J. T. Potts, Jr., A. D. Care, G. P. Mayer, and G. D. Aurbach. 1966. Evaluation by radioimmunoassay of factors controlling the secretion of parathyroid hormone: intravenous infusions of calcium and ethylenediamine tetraacetic acid in the cow and the goat. Nature (Lond.). 209:52-55.

2. Habener, J. F., and J. T. Potts, Jr. 1976. Relative effectiveness of magnesium and calcium on the secretion and biosynthesis of parathyroid hormone in vitro. Endocrinology. 98:197-202.

3. Brown, E. M., D. G. Gardner, M. F. Brennan, S. J. Marx, A. M. Spiegel, M. F. Attie, R. W. Downs, J. L. Doppman, and G. D. Aurbach. 1979. Calcium-regulated parathyroid hormone release in primary hyperparathyroidism. Studies in vitro with dispersed parathyroid cells. Am. J. Med. 66:923-931.

4. Keaton, J. A., J. A. Barto, M. P. Moore, J. B. Gruel, and G. P. Mayer. 1978. Altered parathyroid response to calcium in hypercalcemic neonatal calves. Endocrinology. 103:2161-2167.

5. LeBoff, M. S., H. G. Rennke, and E. M. Brown. 1983. Abnormal regulation of parathyroid cell secretion and proliferation in primary cultures of bovine parathyroid cells. Endocrinology. 113:277-284.

6. Brown, E. M. 1981. Relationship of cAMP accumulation to PTH release in dispersed cells from pathologic human parathyroid tissue. J. Clin. Endocrinol. Metab. 52:961-968.

7. Brown, E. M., N. Adragna, and D. G. Gardner. 1981. Effect of potassium on PTH secretion from dispersed bovine parathyroid cells. J. Clin. Endocrinol. Metab. 53:1304-1306.

8. Shoback, D., J. Thatcher, R. Leombruno, and E. Brown. 1983. Effects of extracellular $\mathrm{Ca}^{2+}$ and $\mathrm{Mg}^{2+}$ on cytosolic $\mathrm{Ca}^{++}$and PTH release in dispersed bovine parathyroid cells. Endocrinology. 113:424426.

9. Brown, E. M., and J. G. Thatcher. 1982. Adenosine 3',5'monophosphate (cAMP)-dependent protein kinase and the regulation of parathyroid hormone release by divalent cations and agents elevating cellular cAMP in dispersed bovine parathyroid cells. Endocrinology. 110:1374-1380.

10. Tsien, R. Y., T. Pozzan, and T. J. Rink. 1982. Calcium homeostasis in intact lymphocytes: cytoplasmic free calcium monitored with a new intracellularly trapped fluorescent indicator. J. Cell Biol. 94:325-334.

11. Brown, E. M., E. J. Watson, R. Leombruno, and R. H. Underwood. 1983. Extracellular calcium is not necessary for acute, low calcium or dopamine-stimulated PTH secretion in dispersed bovine parathyroid cells. Metabolism 32:1038-1044. 
12. Lee, M. J., and S. I. Roth. 1975. Effect of calcium and magnesium on deoxyribonucleic acid synthesis in rat parathyroid glands in vitro. Lab. Invest. 33:72-79.

13. Brown, E. M. 1980. Calcium-regulated phosphodiesterase in bovine parathyroid cells. Endocrinology. 107:1998-2003.

14. Brown, E. M. 1983. Four parameter model of the sigmoidal relationship between parathyroid hormone release and extracellular calcium concentration in normal and abnormal parathyroid tissue. $J$. Clin. Endocrinol. Metab. 56:572-581.

15. Shoback, D. M., J. Thatcher, R. Leombruno, and E. M. Brown. 1984. Relationship between PTH secretion and cytosolic calcium concentration in dispersed bovine parathyroid cells. Proc. Natl. Acad. Sci. USA. 81:3113-3117.

16. Brown, E. M., M. F. Brennan, S. Hurwitz, R. Windeck, S. J. Marx, A. M. Spiegel, J. O. Koehler, D. G. Gardner, and G. D. Aurbach. 1978. Dispersed cells prepared from human parathyroid glands: distinct calcium sensitivity of adenomas vs primary hyperplasia. J. Clin. Endocrin. Metab. 46:267-276.

17. Habener, J. F. 1978. Responsiveness of neoplastic and hyperplastic parathyroid tissues to calcium in vitro. J. Clin. Invest. 62:436458.

18. Brown, E. M., R. E. Wilson, R. C. Eastman, J. Pallotta, and S. P. Marynick. 1982. Abnormal regulation of parathyroid hormone release by calcium in secondary hyperparathyroidism due to chronic renal failure. J. Clin. Endocrinol. Metab. 54:172-179.

19. Purnell, D. C., L. H. Smith, D. A. Scholz, L. R. Elveback, and C. D. Arnaud. 1971. Primary hyperparathyroidism: a prospective clinical study. Am. J. Med. 50:670-678.
20. Lloyd, H. M. 1968. Primary hyperparathyroidism: an analysis of the role of the parathyroid tumor. Medicine. 47:53-71.

21. Castleman, B., and T. B. Mallory. 1935. The pathology of the parathyroid gland in hyperparathyroidism. A study of 25 cases. Am. J. Pathol. 11:1-69.

22. Parfitt, A. M. 1969. Relation between parathyroid cell mass and plasma calcium concentration in normal and uremic subjects. Arch. Intern. Med. 124:269-273.

23. Lloyd, H. M., J. M. Jacobi, D. Willgoss, J. Kearney, and P. Ward. 1981. DNA synthesis and secretory activity in parathyroid adenomas. Acta Endocrinol. 96:70-74.

24. Maciag, T., J. Kadish, L. Wilkins, M. Stemerman, and R. Weinstein. 1982. The organizational behavior of human umbilical vein endothelial cells. J. Cell Biol. 94:511-20.

25. Weinstein, R., M. B. Stemerman, D. E. MacIntyre, H. N. Steinberg, and T. Maciag. 1981. The morphological and biochemical characterization of a line of rat promegakaryoblasts. Blood. 58:110121.

26. Scott, R. E., J. J. Wille, and M. L. Wier. 1984. Mechanisms for the initiation and promotion of carcinogenesis: a review and a new concept. Mayo Clin. Proc. 59:107-117.

27. Pardee, A. B., R. Dubrow, J. L. Hamlin, and R. F. Kletzien. 1978. Animal cell cycle. Annu. Rev. Biochem. 47:715-750.

28. Scott, R. E., D. L. Florine, J. J. Wille, Jr., and K. Yun. 1982. Coupling of growth arrest and differentiation at a distinct state in the $\mathrm{G}_{1}$ phase of the cell cycle: GD. Proc. Natl. Acad. Sci. USA. 79:845849. 